\title{
The Brazilian monetary and fiscal policies from 2011 to 2017: conventions and crisis
}

Philip Arestis - Professor of Economics, University of Cambridge, UK, and University of the Basque Country, Spain. E-mail: pa267@cam.ac.uk

Fernando Ferrari Filho - Retired Professor of Economics, Federal University of Rio Grande do Sul, and Researcher at Council for Scientific and Technological Development, Brazil. E-mail: ferrari@ufrgs.br

Marco Flávio Resende - Assistant Professor at Federal University of Minas Gerais and Council for Scientific and Technological Development, Brazil. E-mail: resende@cedeplar.ufmg.br

Fábio Bittes Terra - Assistant Professor at Federal University of ABC and Council for Scientific and Technological Development, Brazil. E-mail: fhbterra@gmail.com

Post Keynesians define conventions as creeds shared by individuals who use them to ground their expectations. Economic policymaking plays a major role in the development of conventions. Thus, this article analyses Brazil's fiscal and monetary policies over 2011-2017. First, it shows how the monetary policy over 2011-2014 wasted the opportunity to establish a lower base rate in Brazil, what we call 'the mistakes of the past'. Second, it argues that the austerity policy implemented after 2015 formed the convention that public investments are not needed to boost private investments; this is what we call 'the loss of future opportunities'.

\section{Introduction}

In Chapter 18 of The General Theory of Employment, Interest and Money (GT), and when summarising the book's idea, Keynes (1964) states that the three variables that explain the dynamics of employment, income and wealth creation in the economy are the propensity to consume, the expectation of capital assets' future yield and the liquidity preference. Amongst these variables, investment expectations and liquiditypreference are both crucial to galvanising the economy; moreover, they have a strong causal relationship: worse expectations lead to liquidity-preference and lower productive investment, and vice versa. Also, as expectations and liquidity-preference are subjective, they comprise another side of human behaviour, namely uncertainty. In view of uncertainty, there is no sureness about the future, only expectations; so, it is important to understand the grounds for them.

Expectations are founded on "partly existing facts which we can assume to be known more or less for certain, and partly future events which can only be forecasted 
with more or less confidence" (Keynes 1964, 147). In the GT, among the more or less well known considerations, Keynes highlights one in particular: conventions, which are beliefs shared by individuals that help them to form their expectations for the future. Among the most important conventions are those as to how to conduct economic policies, particularly fiscal, monetary and exchange policies. They are responsible for constituting a basis for private expectations and also, nonetheless, for shaping an institutional structure that creates an environment favourable to private sector decisions to invest, which are fundamental to long-term economic dynamics.

Given that, the aim of this article is to examine the Brazilian economic policies, particularly monetary and fiscal policies, from 2011 to 2017. In this context, two analyses specifically are performed. On the one hand, it is shown how the adoption of economic policies from 2011 to 2014 brought conventions into disarray, thus wasting the opportunity to bring the historically high Brazilian interest rates to a lower plateau. We call this wasted opportunity as 'the mistakes of the past'. On the other hand, this contribution describes and analyses how, after 2015, fiscal policy has been structured along 'expansionary contraction' lines, both in efforts to achieve a short-term fiscal adjustment; and in the proposed New Fiscal Regime, the so-called 'Fiscal Spending Cap Amendment' approved by the National Congress in December 2016, also supported by the Michel Temer government, which constrained public spending in the government's endeavour to forcefully deliver fiscal consolidation. The idea is to make it clear that, had a fiscal reform along the lines of Keynesian proposals occurred, there would have been a chance of forming more optimistic long-terms conventions, rather than 'wasting future opportunities', as it is termed here.

To that end, section two discusses the role of conventions in the formation of expectations, which serves as the theoretical framework for analysing the Brazilian 
monetary policy in the period 2011 to 2014 and the fiscal policy post-2015, in order, respectively, to point to 'the mistakes of the past' and the 'waste of future opportunities'. In this sense, the third section examines the monetary policy over 20112014 to show the 'mistakes of the past', while the fourth section presents the 'waste of future opportunities' as being the fiscal consolidation adopted in Brazil in the period after 2015. The fifth section offers some final remarks.

\section{The role of conventions in the formation of expectations}

On a number of occasions, Keynes made it clear that Economics is a moral science and thus deals with human behaviour. ${ }^{1}$ In that respect, and in the Treatise on Probability (TP), Keynes, (1921) went as far as to present an epistemological model to understand human reasoning, at least at the individual decision-making level. It is in this respect that conventions influence expectations. In the TP, Keynes (op. cit.) sets himself a complex task, namely to show that the reasoning that proves itself mistaken is just as rational as that which proves right. In this respect, he asks "is it certain that Newton and Huyghens were only reasonable when their theories were true, and that their mistakes were the fruit of a disordered fancy?" (Keynes 1921, 284). In order to address that task, Keynes developed an epistemological analysis in the TP upon which it is possible to understand the 'Keynesian entrepreneur' of the GT.

Knowledge begins with 'direct acquaintance', that is, the absorption of some datum or evidence by means of an inborn human ability to perceive facts by experience, to understand meanings and to use them as appropriate. Direct acquaintance offers individuals a series of data that they know with greater or lesser certainty, constituting what Keynes (1921) calls 'direct knowledge'. Direct knowledge, in turn, is the basis 
upon which to form propositions, which the TP defines as indirect knowledge; that is, something that necessarily goes beyond the series of data from which it is formed. ${ }^{2}$

Such a proposition, the indirect knowledge, is precisely the entrepreneurs' expectations for the future. It is produced by an inductive reasoning, which draws on particulars (data/evidence, direct knowledge) in order to attain a general argument (proposition/conclusion, indirect knowledge), and "shares the uncertainty to which all inductions are liable" (Keynes 1921, 95).

The data from which individuals acquire direct knowledge include this belief shared with other individuals, that is, conventions, even though "convention is not rooted in secure knowledge" (Keynes 1964, 204). Thus, a convention is a prevailing shared conviction over time, which economic agents add to their direct knowledge. This is, if not because they hold it as the truth, at least because "worldly wisdom teaches that it is better for reputation to fail conventionally than to succeed unconventionally" (Keynes 1964, 158).

Moreover, given that a convention can be "a tool to coordinate expectations, to inform each one about what others expect as an outcome of a given stimulus" (Carvalho 2014,257 , translated by the authors), the greater other economic agents' adherence to a given convention is, it inspires greater confidence of each individual in the future continuity and rightness of this convention in particular - a type of self-fulfilling prophecy. Therefore, governments, which are the greatest social entity and have the power of creating and enforcing public policy, play a key role in forming conventions and consequently in establishing expectations.

With this in mind, one can understand why Keynes proposed ways of conducting economic policy. ${ }^{3}$ Restricting our presentation to monetary and fiscal policies, and focusing on Keynes' monetary policy, and as Arestis, Terra and Ferrari 
Filho (2018) show, its utmost intention is the achievement of full employment. This intention, however, should align with other economic policies, because monetary policy alone is unable to accomplish it, and coordination of policies is very important. Nonetheless, Keynes (1982) argues that monetary policy has other five goals under its direct responsibility: prices, exchange rate, liquidity, financial and expectations stabilities. In that connection, Arestis, Terra and Ferrari Filho (2018) point out that, in his various writings, Keynes showed that central banks have three instruments with which to attain their immediate goals: the interest rate, regulation and debt administration.

The base interest rate is "the governor of the whole system" (Keynes 1971, 189) so that it is the main tool of monetary policy and acts on economic agents' liquiditypreference, which, on the one hand, depends on the economic agents' expectations and, on the other, explains the reason for speculative demand for money and so defines the market interest rate. In light of this argument, the central bank has to build positive conventions regarding how it intends to administer its base rate over time. In fact, Keynes makes it clear that "a monetary policy which strikes public opinion as being experimental in character or easily liable to change may fail” (Keynes 1964, 203). However, it "may prove easily successful if it appeals to public opinion as being reasonable and practicable and in the public interest, rooted in strong conviction, and promoted by an authority unlikely to be superseded" (Keynes 1964, 203).

In terms of fiscal policy, Keynes (1980) proposed a progressive tax policy, that should raise funds to finance public spending and promote income distribution. Spending, in turn, would comprise a budget segregated into current and capital expenditures. Current expenditures would finance public services and should tend to operate in surplus. Capital expenditures would automatically stabilise the economic 
cycle via long-term public investment programmes, that is, to build infrastructure for the private productive structure - which if not undertaken by the State, it cannot be initiated. Clearly, the State is thus not to compete with the private sector, but to cooperate with it, aiming at creating a crowding in effect.

It is important to note that the capital budget should be financed by taxes and by the current budget surpluses. Moreover, it should be counter-cyclic: in an economic boom, public investments should diminish, but they would expand at the first signs that effective demand is cooling, so as to fill the gap left by reduced private spending. In this way, fiscal policy would anchor positive conventions as to the future and would seek to promote private crowding-in. For this reason, Keynes (1980) was concerned that there should be no deficit financing of the public budget, because this could both undermine confidence about future State financing and put pressure on short- and long-term interest rates, as a result of public demand for liquidity in the financial system.

One last point concerning conventions and economic policy, Ferrari Filho and Conceição (2005) argue that Keynes's (1964) notion of 'socialisation of investment' can be understood as the State constructing a stable institutional structure, favourable to private spending. Thus, stable rules are needed to foster conventions, embodying the belief in the permanence of the present state of affairs in the future, which is fundamental for entrepreneurs to invest.

\section{Monetary policy from 2011 to 2014: 'the mistakes of the past'}

In the early months of 2011, the then elected Dilma Rousseff government sought to gain credibility: the primary surplus target was announced as in excess of $3 \%$ of GDP (and was met) and the Central Bank of Brazil (BCB) raised the base (Selic) interest rate to $12.5 \%$ in August 2011 (BCB 2018). At its September 2011 meeting, the Monetary 
Policy Committee embarked on a process of reducing the Selic rate, to everyone's surprise, and this continued until October 2012, when the rate reached what was then its lowest value ever, $7.25 \%$ per year.

The BCB's actions successfully managed to lead conventions and market expectations along as shown in Graph 1. Although inflation in 2010 was 5.91\%, nearing the upper target bound of $6.5 \%$ (BCB 2018), market conventions were positive as regards monetary policy. For that reason, the DI pre-360 ex ante market rate - which prices in the present the expected annual interest rate - started forecasting a steadily lower future Selic rate, as the line traced in the Graph reports.

Graph 1 - Brazilian Central Bank Interest Rate, Market Future Interest Rate and Expected Inflation Gap, 01/2011 to 12/2016

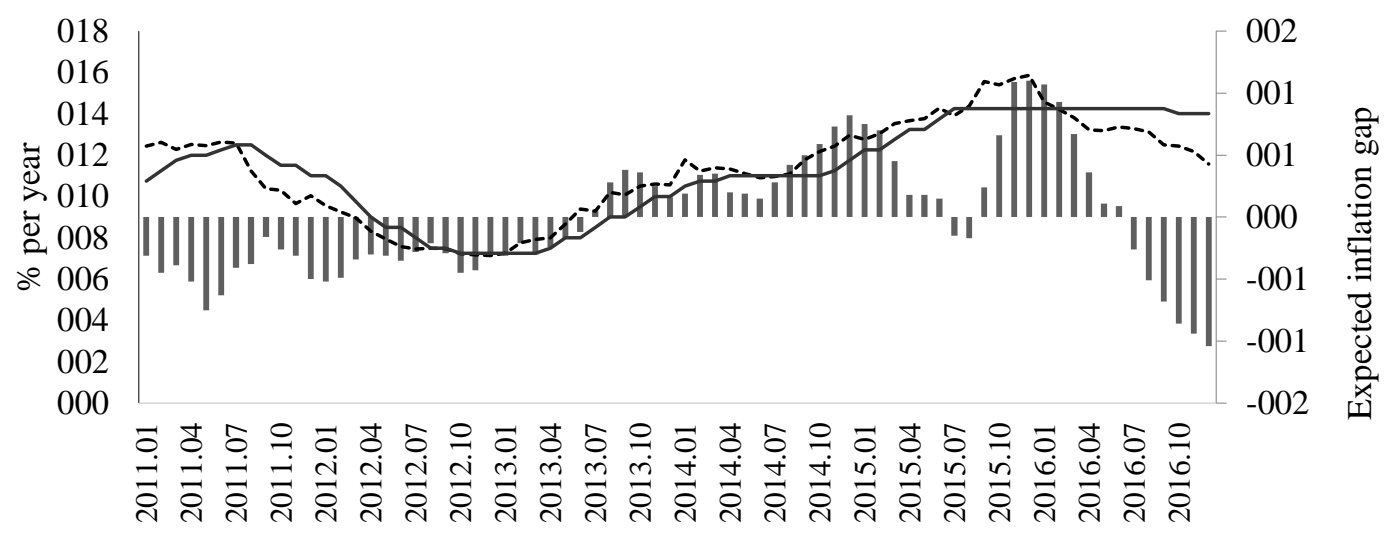

Expected Inflation Gap ------- Market's Future Interest Rate — Central Bank Interest Rate

Source: BCB (2018).

Note: (i) The expected inflation gap is the difference between the inflation expected at each point and its average value over the whole period.

Accordingly, economic agents - not just financial market operators, but all those with an active position on interest rates, such as families and companies carrying portfolios of financial assets and savings accounts - purchased at lower nominal and real interest rates, and relied on that scenario continuing from that point on into the future. One of the central reasons for this was the diminishing expected inflation gap, that is, economic agents believed that inflation would decrease, as the negative bars 
relative to the Graph's secondary axis displays. As inflation is a risk that erodes asset values (particularly fixed income ones), the lower its future expected rates are, the lesser is the asked liquidity-preference premium, enabling lower interest rates. In short, from 2011 to mid-2013, the reduction of the Selic rate was successful and established the convention that future interest rates would remain at low levels.

Why did conventions change? Graph 1 shows that, from mid-2013 on, future interest rates began to embody a higher risk premium. Worse, future conventions began to contaminate expectations, and the expected inflation gap migrated to the positive field. What was happening? Conventions were in disarray in various domains. In the monetary domain, the government begun to use the upper bound of the band as its pursued inflation target. Inflation rate in Brazil reached 6.5\% in 2011, 5.84\% in 2012, $5.91 \%$ in 2013 and $6.41 \%$ in 2014 (BCB 2018), amounting to prices $27 \%$ high in four years. Obviously, in view of the risk of wealth being eroded by inflation, any relinquishing of liquidity would call for a higher liquidity premium: market interest rates started going up and began to decouple from the Selic rate.

The reasons why inflation behaved in this way are to be found, on the one hand, on cost factors, namely the BCB's controlled exchange devaluation, in which the US dollar appreciated by an accumulated 42\% between January 2011 and December 2013 (BCB 2018) and increasing commodity prices, that rose by $11 \%$ at that same period (BCB 2018), pressuring production costs and thus prices. On the other hand, after 2012, demand factors also exerted a role on pushing inflation up, especially so as the government expanded its own spending, particularly in public consumption. As SPE (2018) reports, the government gave a fiscal stimulus equivalent to $0.6 \%$ of GDP in 2012 and $1 \%$ in 2013, with public consumption growing at a mean quarterly rate of $2.7 \%$ between 2011 and 2013 . 
In that period, however, as a result of expanding household consumption, which was growing at a mean quarterly rate of $4 \%$, private enterprise was increasing its gross fixed capital formation by a quarterly mean of around $4.5 \%$. That is, the government stepped on the fiscal accelerator at a moment when private enterprise was also accelerating. Finally, in the same period, exports also grew by a higher quarterly mean of $3.1 \%$. Accordingly, Brazil was not facing problems of demand; on the contrary, the constraints encountered were supply issues, as the mean quarterly expansion of $7.5 \%$ in imports, which meant a variation of $17 \%$ in the imported quantum between January 2011 and December 2013. It is also worth highlighting that this rising quantity reached 48\% more in October 2013 in relation to January 2011 (IBGE 2018); and that was so despite the mentioned exchange rate depreciation observed between 2011 and 2013.

An accelerating demand, in turn, encountered quite a buoyant labour market, with unemployment rates falling from 6\% in January 2011 to 4.3\% in December 2013, as shown by the former monthly employment survey, or from $7.9 \%$ in the first quarter of 2012 to $6.2 \%$ in the last quarter of 2013, in figures of the actual unemployment research in Brazil ${ }^{4}$ (IBGE 2018). Low unemployment pushed wages up and the labour real income expanded by a moving average of $2.1 \%$ in 2012 and $3.7 \%$ in 2013 (IBGE 2018). Of course, higher wages meant increases in costs, which were passed on to prices. Also, to demonstrate how Brazil was facing constraints to expand its production, the mean installed industrial capacity was $82 \%$ in the period, meaning a lack of supply to meet an accelerating demand (BCB 2018).

The inflationary pressures thus came from both rising costs and the lack of labour supply to cope with a growing aggregate demand. Thereafter, if the BCB's intention was to reduce the Selic rate to historically low levels, while devaluing Brazil's currency (which we consider appropriate), the government should not have accelerated 
budget growth. Private investment was doing its part, at mean quarterly growth rates of $6.9 \%$ in $2011,0.8 \%$ in 2012 and $5.8 \%$ in 2013.

Despite these cost-demand factors acting on inflation, there were four other 'mistakes of the past', three of them were still related to fiscal issues and all conspired to dissipate the opportunity for low interest rates to be maintained and become a convention: (i) fiscal expansion was carried out in a manner that lacked credibility, using devices that inspired mistrust (among them the "creative accounting" ${ }^{5}$ or the use of non-recurrent funds, such as selling oil fields, which are State owned by law); (ii) the efforts to communicate fiscal policy measures to public opinion were particularly poor and limited to an insistence on announcing unrealistic revenue expansion and primary surplus goals; (iii) fiscal policy gave out conflicting signals, in that a tax relief policy was introduced between 2011 and 2014 in parallel with increasing public outgoings (Resende and Terra 2017, 263-264). As growing public investment and consumption were happening together, with large tax exemptions, the primary balance was incompatible with forming the surplus required to sustain the federal government large disbursements on interest and amortization; thereby making the nominal deficits of the government grow steadily, which needed to be financed by an increasing public debt and at a higher interest rate. Thus, the ratio of the federal interest payments to GDP went up from an average of $3.05 \%$ in 2013 to $6.07 \%$ in 2015 (IPEADATA 2018); ${ }^{6}$ and (iv) coming back to monetary policy, the government used price freezing to control inflation, a method the Brazilian people are very sensitive to, and suspicious of the result of their experiences with high inflation in the 1980s and 1990s.

To sum up 'the mistakes of the past', the interest rate reductions between 2011 and 2012 were successful, in that they managed to form conventions that generated favourable expectations for the continuance of lower rates in the future. However, as 
interest rates are the price of liquidity-preference and depend on conventional relations and the state of expectations, from mid-2013 onwards, economic agents' expectations reversed, because the economic authorities decided to accelerate demand in Brazil, an endeavour to achieve high levels of economic growth at a time when it was not demand that was proving insufficient and thus did not need to be accelerated, but merely maintained. As Keynes (1964) shows, stimuli on effective demand have repercussions on production and prices. In Brazil from 2011 to 2013, supply was quite inelastic, so that prices responded more intensely, when cost-push inflation was already in place, strengthening economic agents' perceptions of the risk of inflation. When this became a convention and economic agents began to price inflation into premiums for relinquishing the liquidity they held, market interest rates increased (see Graph 1), obliging the BCB to resume Selic rate increases in mid-2013. Had it not been done so, the $\mathrm{BCB}$ would have been unable to control the short end of the interest rate curve, which would be even more serious for private investment.

Lastly, an exogenous element was also making things harder for the Brazilian economy. In 2014, the 'Operation Carwash' lawsuit, an economically significant factor, although not produced by economic policy, but due to the already in course 'mistakes of the past' that worsen expectations and foster pessimistic conventions and greater liquidity-preference, partly explain the abrupt and deep two-year Brazilian recession, 2015 and 2016. 'Operation Carwash' directly affected Brazil's largest corporation, Petrobras (which alone accounted for 8.9\% of aggregate investment in Brazil in 2013 (Loural 2016)), as well as major contractors, responsible for building infrastructure investments. As a result, aggregate investment declined by $13.9 \%$ in real terms in 2015 and by $10.3 \%$ in 2016 (Ipeadata 2018). 


\section{Fiscal policy after 2015: 'loss of future opportunities'}

As mentioned before, the Dilma Rousseff government's lack of fiscal control from 2014 onwards, ${ }^{7}$ increased public indebtedness and strongly pushed up interest rates on National Treasury bonds. Finally, in an attempt to solve the issue, fiscal austerity measures were undertaken, at first short-term ones through a sweeping programme of reducing public spending, but later, December 2016, it was swapped to a structural, permanent policy, under the enforcement of a constitutional rule assuring the New Fiscal Regime (NFR). Thus, unlike of the 'mistakes of the past', in which there was an accelerating demand, what came into play in Brazil after 2015 was insufficient demand, precisely the opposite of what had existed previously. In that situation, in which State action was called for, it was not forthcoming.

The short-term adjustment of 2015-2016 was carried out on the basis of restrictions on the release of public expenditures. In 2015, these failed to yield results, as total real expenditures rose; however, in 2016 they did decline in real terms to levels close to those of 2014 (TN 2018). By late 2016, fiscal consolidation entered a new phase in that the NFR limited any increase in public spending to slow inflation, as measured by the consumer price index. In that way, the NFR made clear its intention to reduce State participation in the economy. The short-term adjustment of 2015-2016 harmed the State's ability to galvanise the economy; the structural adjustment resulted in a structural compression of public investments.

Certainly, 2015 and 2016 were years in which the federal government needed to reorder its finances, because economic agents' conventions regarding the sustainability of the federal budget were considerably negative, entailing risk premiums that called for higher annual interest rates, which helped raising interest payments from $3.5 \%$ do GDP in December 2013 to $7.22 \%$ in January 2016 (Ipeadata 2018). Even though public 
spending austerity might have fostered conventions of fiscal reorganisation, it was unlikely to foster conventions of an expanding economic dynamic that were sufficiently vigorous to become something private investment could count on.

Moreover, it is questionable whether the expectation of fiscal austerity would foster optimistic conventions regarding the adjustment of public accounts. This is so because instead of contributing to shrinking effective demand and thus GDP, the cut in public spending in a scenario of economic recession helped to lead to a fall in government revenue. Once again, the fiscal policy adopted was pro-cyclical, stimulating negative conventions; not only regarding the lack of fiscal equilibrium but also the federal government's inability to lead a recovery from the recession that worsened over the course of 2015 .

Thus, given the degree of Brazil's budget rigidity, with receipts legally attached to a specific spending, which leaves no easy margins of manoeuvre for changing the destination of the expense, the fiscal adjustment should have proposed emergency expansion of revenue, partly in order to restore the primary surplus, and partly to supplement credit in public investment. In fact, there was little political scope for Brazil's congress to support such measures, but no proposals in this direction even emerged from the parliamentary debates, and no conventions were formed concerning options, except harmful austerity. ${ }^{8}$

As regards the structural adjustment via the NFR, the convention that has become established since then is that the government will make no further public investments. In our view, the NFR should actually have looked at both sides of any fiscal policy: public revenues and expenditure of public funds. Nonetheless, the one passed in Brazil limited itself to considering primary expenditures, with no rationale other than that of reducing the size of the State in the economy and being completely 
independent of the behaviour of public revenues or GDP, with expenditures being corrected solely by inflation. Having begun the NFR with a ceiling limiting overall expenditures and with no subsequent measures being approved to enable compliance with the rule, it remained to the government - immediately rather than gradually - to compress public investments; this is one of the few non-rigid expenditures used as an escape way in order to comply with the upper limit rule.

The NFR was a lost opportunity because in addition to disregarding taxation, it missed the chance to build a budget organization in Brazil that would use public investment effectively to stabilize the economic cycle, by counter-cyclic administration of investment outgoings and with no need to incur fiscal deficits for that purpose. If the fiscal adjustment process had been widely discussed with public opinion and if there had been a commitment by the State (including Brazil's states and municipalities and not just the federal government) to balance the public sector, positive conventions could have arisen; thereby contributing to the formation of expectations favourable to private investment decision-making.

Instead of relying on expansionary fiscal contraction, the logic of Keynes (1980) would demand expansionary fiscal responsibility through the building of a fiscal regime with a trimmer, less rigid current budget and primary surplus targets designed to finance investments in a capital budget. In fact, the fiscal consolidation debate in Brazil is structural, not so much in the sense that the State is too large, but on the rationale that public expenditures do little to promote conventions in favour of investment. Brazil could have taken a turn in that direction, but unfortunately, with the NFR, the chance was wasted. 


\section{Final remarks}

Conventions are shared beliefs that ground expectations, although they are just as subjective as expectations themselves. The effect of economic policy depends greatly on its success in building (or not hindering) economic agents' conventions and maintaining them over time. In this respect, the analyses of the undertaken monetary policy between 2011 and 2014, and fiscal policy after 2015, show the importance of administering economic agents' conventions, both so as not to transform an initially successful policy into a disaster (as with the interest base rate reductions over 20112014) and not to lose the opportunity to build a public budget that serves as effective anchorage and complementation for private investments (unlike the short-term fiscal adjustment of 2015 and 2016 and the structural adjustment, via the NFR, after December 2016).

The convention post-NFR is that there will be no more public investment to serve as a beacon for private investments - this stimulus to private investment is, as mentioned above, unrelated to tax relief, subsidies or trade barriers, which generate only privileges and distortions. Brazil has scanty infrastructure on which a private structure can be built upon. Accordingly, with the NFR in place, there is no room for the public sector to galvanise such a structure, and the domestic rate of return on such investments is unlikely to encourage private investment.

\section{References}

Arestis, Philip, Terra, Fábio Bittes, and Ferrari Filho, Fernando. 2018. Keynesian Macroeconomic Policy: theoretical analysis and empirical evidence. Panoeconomicus, 65 (1), 1-20. https://doi.org/10.2298/PAN1801001A

Banco Central do Brasil. 2018. "Séries Temporais". Accessed April 16, 2018.

http://www.bcb.gov.br/pt-br/\#!/n/SERIESTEMPORAIS, 
Carvalho, Fernando Cardim. 2014. "Expectativas, Incerteza e Convenções”. In Estratégias de Desenvolvimento, Política Industrial e Inovação: ensaios em memória de Fabio Erber edited by Dulce Corrêa Monteiro Filha, Luis Carlos Delorme Prado, and Lastres, Helena Maria, 235-262, Rio de Janeiro: Banco Nacional de Desenvolvimento Econômico e Social

Ferrari Filho, Fernando and Conceição, Octávio. 2005. The Concept of Uncertainty in Post Keynesian Theory and in Institutional Economics. Journal of Economic Issues, 39 (3), 579-594.

Gobetti, Sérgio, and Orair, Rodrigo. 2016. "Progressividade Tributária: a agenda negligenciada”. IPEA Texto para Discussão 2190, Instituto de Pesquisa Econômica Aplicada, Brasília.

Instituto Brasileiro de Geografia e Estatística. 2018. "Estatísticas”. Accessed April 16, 2018.

https://www.ibge.gov.br/estatisticas-novoportal/sociais/trabalho.html

IPEADATA. 2018. "Séries Históricas”. Accessed April 16, 2018. http://www.ipeadata.gov.br

Keynes, John Maynard. 1921. Treatise on Probability. London: MacMillan.

Keynes, John Maynard. 1964. The General Theory of Employment, Interest and Money. HBS: New York.

Keynes, John Maynard. 1971. A Treatise on Money: the applied theory of money (The Collected Writings of John Maynard Keynes, volume VI). London: McMillan/Royal Economic Society.

Keynes, John Maynard. 1973. The General Theory and After: defence and development (The Collected Writings of John Maynard Keynes, volume XIV). London: MacMillan/Royal Economic Society.

Keynes, John Maynard. 1980. Activities 1940-1946: Shaping the Post-War worldemployment and commodities (The Collected Writings of John Maynard Keynes, volume XXVII). London: MacMillan/Royal Economic Society.

Keynes, John Maynard. 1982. The Monetary Policy of the Labour Party (The Collected Writings of John Maynard Keynes, volume XXI). London: McMillan/Royal Economic Society.

Loural, Marcelo Silva. 2016. Investimentos Industriais no Brasil: uma análise setorial do período 1999-2013. PhD thesis, Institute of Economics, Campinas State University. 
Resende, Marco Flávio and Terra, Fábio Bittes. 2017. "Economic and Social Policies Inconsistency, Conventions and Crisis in the Brazilian Economy, 2011-2016". In The Brazilian Economy since the Great Financial Crisis of 2007/08, edited by Philip Arestis, Daniela Magalhães Prates e Carolina Baltar, 245-272, Basingstoke: Palgrave Macmillan.

Secretaria de Política Econômica. 2018. "Resultado Primário Estrutural: Boletim". Ministério da Fazenda, Secretaria de Política Econômica. Brasília.

Tesouro Nacional. 2018. Estatísticas Fiscais. Accessed April 16, 2018. https://www.tesouro.fazenda.gov.br/-/area-tematica-5-estatisticas-fiscais

\section{Endnotes}

${ }^{1}$ For Keynes, the idea of Economics being a Moral Science is very clear in a letter he wrote to Roy Harrod in 1938. In this letter, Keynes states "I also want to emphasise strongly the point about economics being a moral science [...] it deals with motives, expectations, psychological uncertainties." (Keynes 1973, 300).

${ }^{2}$ For this reason also, (i) it is not excessive to say that, in the GT, uncertainty is a result of the epistemological model formulated by Keynes in the TP and not an ad hoc hypothesis necessary to the book's theoretical analysis; and (ii) the fundamental uncertainty based on the fact that not all the data relevant to taking a decision are available, stems from the nature of inductive reasoning, whose propositions always go beyond the evidence substantiating them, to create a priori a conclusion that exists for the decision maker alone.

${ }^{3}$ The economic policy agenda proposed by Keynes is known to address both fiscal, monetary and trade issues as well as structural changes.

${ }^{4}$ This new research is the 'Continuous National Survey by Household Sample' (in Portuguese, Pesquisa Nacional por Amostra de Domicílios Contínua, PNAD), which is the Brazilian unemployment survey since 2012. To illustrate the period prior to 2012 we reported both data.

5 'Creative accounting' is the use of artificial manners to reach fiscal equilibrium. The most famous creative accounting method was the so-called 'fourfold operation', evolving the exchange of resources between the State and its own firms. The four public entities that took part in the scheme were the National Sovereign Fund, National Treasury, BNDES (public development bank) and Caixa Econômica Federal (commercial public bank). They changed assets and loans between them in such a way that in the end the National Treasure accomplished the amount necessary to fulfil the primary balance surplus it had committed with the Brazilian Parliament. To see more on this odd public finance behaviour, see Villaverde (2016).

${ }^{6}$ Itens (i) to (iii) pushed the long-end of the yield curve up, and forced the Selic up; otherwise the BCB would have less influence over the term structure of the interest rate in Brazil.

${ }^{7}$ SPE (2018) shows there was a structural deficit from 2013 onwards, which was only covered with extraordinary non-recurrent receipts. 
${ }^{8}$ Had there been such political scope, the necessary redressing of fiscal balance should also have been achieved by permanently increasing government revenues, with a view to prevent further worsening in deficient demand in a context of economic slowing or recession, by way of taxation on the wealthiest. However, proposals such as taxation of profits and dividends - which Gobetti and Orair (2016) argue, would constitute an important reinforcement to the fiscal adjustment - taxation of inheritances and regulation of the tax on large fortunes, and other measures, were not considered. 